\title{
KAJIAN TERHADAP TINGKAT KINERJA EKSPOR \\ INDONESIA DALAM RANGKA MENINGKATKAN \\ KESEJAHTERAAN MASYARAKAT: \\ STUDI KASUS EKSPOR UDANG BEKU INDONESIA
}

\author{
M. Takdir Mulyadi ${ }^{1}$
}

\begin{abstract}
The is aimed to know the performance level and the Indonesia's Strategy of frozen shrimp export. The Research is done by using Revealed Comparative Advantage Analysis and SWOT Analysis. The result of this research showed that the level of Indonesia's frozen shrimp export performance less than Thailand's. The recommended strategy that can be done to increase the performance frozen shrimp export are: more focus in developing economic in fishery sector, investment, law deregulation in fishery sector
\end{abstract}

Keywords: income per capita, level on export performance and SWOT analysis

\section{ABSTRAK}

Penelitian bertujuan mengetahui tingkat kinerja ekspor hasil perikanan laut Indonesia (khususnya udang beku) dan posisi strategi yang dijalankan Indonesia. Penelitian dilakukan dengan analisis Revealed Comparative Advantage (RCA) dan analisis SWOT. Hasil penelitian menunjukkan bahw tingkat kinerja ekspor udang beku Indonesia masih di bawah Thailand. Strategi yang dapat dilakukan untuk meningkatkan kinerja ekspor dalam rangka meningkatkan kesejahteraan masyarakat khususnya nelayan adalah: penekanan prioritas pembangunan ekonomi di sektor perikanan melalui revitalisasi pembangunan di sektor perikanan, meningkatkan investasi di sektor perikanan dan menciptakan kepastian hukum dalam berusaha.

Kata kunci: pendapatan per kapita, tingkat kinerja ekspor dan analysis SWOT

${ }^{1}$ Staf Pengajar Fakultas Ekonomi Jurusan Manajemen, UBiNus, Jakarta 


\section{PENDAHULUAN}

Sebagaimana diamanatkan dalam UUD 1945, bahwa salah satu tujuan Negara adalah mensejahterakan rakyat. Upaya untuk meningkatkan kesejahteraan rakyat Indonesia telah dilakukan sejak awal berdirinya republik ini melalui berbagai kebijaksanaan yang dibuat oleh rezim-rezim yang berkuasa seperti: orde lama, orde baru, orde reformasi dan pemerintahan yang sekarang sedang berjalan. Sebagai contoh, pada zaman orde baru, upaya peningkatan kesejahteraan rakyat Indonesia dilaksanakan melalui rangkaian tahapan pembangunan lima tahun yang kita kenal dengan istilah REPELITA. Perencanaan pembangunan yang teratur dan berkesinambungan ini diharapkan dapat meningkatkan kesejahteraan rakyat. Banyak kendala dan permasalahan yang dihadapi Indonesia untuk menjadi bangsa yang maju, adil-makmur, sejahtera, damai, dan bermartabat. Tetapi yang paling krusial untuk segera diatasi adalah persoalan kemiskinan (40 juta orang), pengangguran (37 juta orang), dan menurunnya daya saing ekonomi bangsa.

Salah satu indicator tingkat kesejahteraan masyarakat adalah pendapatan perkapita dari masyarakat. Pada awal kemerdekaan tingkat pendapatan per kapita masyarakat Indonesia masih sangat rendah. Sejalan dengan pelaksanaan pembangunan yang dicanangkan oleh pemerintah yang berkuasa, tingkat pendapatan perkapita masyarakat Indonesia semakin meningkat. Pada tahun 1995, tingkat pendapatan per kapita Indonesia adalah US\$ 0,80. Dibandingkan dengan negara-negara di kawasan ASEAN Indonesia menempati peringkat nomor dua terbawah setelah Vietnam. Tingkat pendapatan per kapita masyarakat suatu negara diperoleh dari Data Pendapatan Nasional dari negara tersebut. Pendapatan nasional adalah nilai dari seluruh barang dan jasa yang diproduksi oleh masyarakat suatu negara dalam suatu periode tertentu. Produksi dari barang dan jasa yang dihasilkan oleh suatu negara, selain dikonsumsi oleh masyarakat negara tersebut juga diekpor ke negara lain untuk mendapatkan devisa ekspor. Pendapatan nasional merupakan ukuran kinerja ekonomi dari suatu negara dan sekaligus dapat dijabarkan sebagai presentasi tingkat kemakmuran negara tersebut. Ada beberapa faktor-faktor yang mempengaruhi Pendapatan nasional suatu negara, antara lain: konsumsi masyarakat, investasi yang dilakukan oleh pihak swasta, pengeluaran pemerintah dan ekspor-impor yang dilakukan oleh negara tersebut. Dalam kondisi perekonomian dunia yang mengalami resesi, dimana konsumsi dan investasi tidak mampu menggerakkan roda perekonomian, peranan ekspor dalam menggerakkan roda perekonomian negara sangat dibutuhkan, terlebih apabila negara itu mempunyai keunggulan pada suatu jenis komoditi tertentu.

Seiring dengan era globalisasi perdagangan dunia, peranan ekspor suatu negara dirasakan sangat menentukan perekonomian suatu negara. Secara umum komoditas ekspor suatu negara harus mempunyai keunggulan bersaing di pasar global dan domestik. Keunggulan ini sangat dipengaruhi oleh kemampuan negara tersebut untuk mengefisienkan kegiatan berproduksinya dan keunggulan teknologi dari negara tersebut. 
Bagi negara-negara berkembang seperti Indonesia, keunggulan komperatif tidak lagi menjamin untuk memberikan keunggulan dalam memenangkan persaingan, tetapi harus menggalakkan upaya untuk mengefisienkan kegiatan-kegiatan produksinya. Kenyataan menunjukkan bahwa banyak produk-produk kita untuk tujuan ekspor kurang mampu bersaing di pasar global karena faktor harga yang tidak kompetitif. Sebagaimana yang terlihat dipasar beberapa produk dari komoditas pertanian Indonesia masih kurang mampu bersaing di pasar domestik, apalagi kalau bersaing di pasar global. Untuk mengatasi hal tersebut diatas, perlu dilakukan pembenahan secara komprehensif, baik pembenahan di tingkat petani maupun pembenahan di tingkat pembuat kebijaksaan (birokrasi). Dalam melakukan pembenahan ini tidak seluruhnya diberlakukan untuk semua produk. Dalam hal ini tentunya kita harus mengetahui dahulu produk-produk mana saja yang perlu dibenahi, perlu dibuat prioritas produk-produk yang berpotensi untuk mendatangkan devisa yang lebih diprioritaskan.

Dalam kaitan ini penulis mencoba untuk melakukan kajian terhadap potensi ekspor hasil perikanan, khususnya udang beku Indonesia pada masa sebelum terjadinya krisis moneter. Kondisi sumberdaya alam sangat mendukung proses produksi udang beku. Kalau dibandingkan dengan Negara pengekspor udang beku lainnya seperti Thailand, jelas sekali Indonesia sebenarnya lebih unggul sumberdaya alamnya. Namun dalam kenyataannya bahwa volume dan nilai ekspor produk udang beku dari Thailand lebih tinggi di banding Indonesia. Thailand saat ini unggul dalam ekspor udang beku ke pasar dunia, lebih dari 20\% kebutuhan pasar dunia di pasok dari Thailand. Pada tahun 1999, Thailand mendapatkan devisa dari ekspor udang beku sebanyak US\$ 2.2 billion. Hal ini mungkin disebabkan salah satunya oleh rendahnya animo masyarakat dalam kegiatan produksi hasil perikanan. Data menunjukkan bahwa, sejak awal Pelita I (1969/1970) sampai dengan akhir 1996, kredit usaha yang dicurahkan untuk sub sektor perikanan hanya $0,02 \%$ dari total kredit usaha pada waktu itu, artinya bahwa investasi dan usaha di bidang kelautan masih sangat rendah. Wajar bila pada masa lampau kekayaan perikanan laut Indonesia banyak dimanfaatkan secara ilegal (illegal fishing) oleh bangsa asing.

Disamping melakukan pembenahan secara komprehensif dipandang perlu untuk segera melakukan revitalisasi berbagai kegiatan ekonomi yang lesu diterpa badai krisis multidimensi yang hingga kini belum sepenuhnya pulih dan secara simultan membangkitkan sumber-sumber pertumbuhan ekonomi baru (New sources of economic growth). Pada era globalisasi yang bercirikan bordless world, liberalisasi perdagangan, dan persaingan ekonomi antarbangsa yang semakin sengit, segenap kegiatan ekonomi yang kita revitalisasi dan kembangkan harus mampu menghasilkan barang dan jasa yang berdaya saing tinggi. Sehubungan dengan fenomena tersebut, perlu dilakukan suatu kajian yang lebih detail tentang kinerja ekspor udang beku Indonesia dan langkahlangkah yang perlu diambil untuk meningkatkan kinerja tersebut demi peningkatan kesejahteraan rakyat Indonesia. 


\section{PEMBAHASAN}

\section{Perdagangan Internasional}

Berkaitan dengan kinerja ekspor suatu Negara , perlu memahami terlebih dahulu tentang kerangka pemikiran yang berkaitan dengan perdagangan internasional. Menurut Tambunan (2001), pandangan perdagang Internasional dapat dikelompokkan kedalam dua kelompok yaitu Teori Klasik dan Teori Modern. Teori klasik yang umum dikenal adalah teori keunggulan absolute dari Adam Smith dan Teori Keunggulan Komperatif dari John Stuart Mill.

\section{Teori Keunggulan Absolut}

Teori ini dianggap sebagai Teori murni perdagangan internasional. Dasar pemikiran teori ini adalah bahwa suatu negara akan melakukan spesialisasi dan ekspor terhadap suatu jenis barang tertentu dimana negara tersebut memiliki keunggulan absolut dan tidak memproduksi barang sejenis. Dengan kata lain, suatu negara akan mengekspor (impor) suatu jenis barang jika negara tersebut dapat (tidak dapat) membuatnya lebih efisien atau murah dibandingkan negara lain.

\section{Teori Keunggulan Komparatif}

Teori keunggulan komperatif ini merupakan kritik atau penyempurnaan terhadap teori keunggulan absolut. Menurut teori ini, suatu negara akan berspesialisasi pada ekspor suatu barang dimana negara tersebut memiliki keunggulan komperatif terbesar dan impor barang dimana negara tersebut mengalami kerugian komparatif. Dengan kata lain suatu negara akan ekspor suatu barang yang dapat dihasilkan dengan biaya produksi yang lebih rendah dan akan impor barang yang kalau dibuat sendiri memerlukan ongkos produksi yang besar.

\section{Teori Modern}

Dalam teori Modern mengenai perdagangan internasional dikenal teori Hecksher dan Ohlin (H-O). Dasar pemikiran teori ini adalah perdagangan internasional akan terjadi karena Opportunity Costs yang berbeda antara kedua negara tersebut. Perbedaan ongkos alternatif tersebut dikarenakan perbedaan dalam jumlah faktor produksi yang dimiliki kedua negara tersebut. Menurut teori ini suatu negara akan berspesialisasi dalam produksi dan ekspor barang-barang yang input (faktor produksi) utamanya relatif sangat banyak di negara tersebut dan impor barang yang input utamanya tidak dimiliki oleh negara tersebut (jumlahnya terbatas)

\section{Paradigma Baru Perdagangan Internasional}

Teori Klasik dan Modern memiliki sejumlah kelemahan, terutama yang berkaitan dengan beberapa asumsi-asumsinya, antara lain tenaga kerja yang dianggap sebagai factor produksi yang dominant dan sifatnya homogen. Kenyataan menunjukkan bahwa tenaga 
kerja tidak homogen, melainkan berbeda menurut jenis dan derajat pendidikan dan keterampilannya. Selain sumberdaya manusia, teori tersebut tidak menganggap pentingnya teknologi, padahal faktor yang terkahir ini sangat berpengaruh terhadap pola serta pertumbuhan perdagangan internasional sejak dekade 1970-an. Bahkan di negaranegara Asia yang miskin sumberdaya alam, seperti Korea Selatan, Singapura, Taiwan, Hongkong dan Jepang, sumberdaya manusia dan teknologi merupakan dua faktor penting penentu kemajuan atau pola perkembangan ekspor negara-negara tersebut.

Karena asumsi-asumsinya tersebut teori modern tidak mampu menerangkan perkembangan ekspor non migas dari negara-negara maju Asia tersebut dan perubahan strukur serta dinamika arus perdagangan global yang mulai nampak jelas sejak awal dekade 1980-an dari komoditas primer ke barang-barang elektronik yang canggih, seperti komputer dan alat-lat telekomonikasi. Pada akhirnya timbul pemikiran bahwa perkembangan ekspor dari suatu negara tidak hanya ditentukan oleh faktor-faktor keunggulan komperatif, tetapi juga oleh faktor-faktor keunggulan kompetitif.

Menurut Michael Porter (1985, 1986, 1990) , hal-hal yang harus dikuasai/dimiliki oleh setiap perusahaan atau negara untuk meningkatkan keunggulan kompetitifnya adalah terutama teknologi; tingkat entrepreunership yang tinggi, tingkat efisiensi/produktivitas yang tinggi dalam proses produksi; kualitas dan mutu yang baik dari barang yang dihasilkan; promosi yang meluas dan agresif , pelayanan teknikal dan non teknikal yang bai (service after sale); tenaga kerja dengan tingkat keterampilan /pendidikan, etos kerja, kreativitas serta motivasi yang tinggi; skala ekonomis; inovasi; diferensiasi produk; modal dan sarana serta prasarana lainnya yang cukup; jaringan distribusi dalam dan terutama di luar negeri yang baik dan well-organized/managed; dan proses produksi yang dilakukan dengan sistem Just in Time (JIT). Faktor-faktor ini semakin penting terutama di pasar internasional dengan persaingan yang semakin tidak sempurna.

Selanjutnya menurut Porter, keunggulan kompetitif ditentukan oleh 4 Determinan, yaitu : (i) keunggulan komperatif, (ii) permintaan di pasar domestik, baik kuantitatif maupun kualitatif, (iii) struktur industri dalam negri yang kuat, (iv) struktur pasar dengan persaingan bebas sepenuhnya.Menurut Porter, untuk meningkatkan keunggulan kompetitif, suatu negara harus menguasai : teknologi, tingkat entrepreunership pengusaha, inovasi dan skala ekonomis. Proses teknologi cenderung menjadi isban produksi yang isbandi dan menentukan perkembangan ekspor dan volume perdagangan.Entrepreneurship merupakan semangat inovasi dan kreatifitas dari para pengusaha.Tidak hanya diperlukan pada proses awal produksi saja, tetapi juga pada saat sebelum maturity 


\section{Tingkat Daya Saing Ekspor}

Tingkat daya saing komoditas ekspor suatu negara atau Industri dapat dianalisis dengan berbagai macam metode atau diukur dengan sejumlah Indikator, antara lain : Revealed comparative Advantage Constant Market Share (RCA) dan Real Effective Exchange Rate (REER) (Tambunan, 2001)

\section{Revealed Comparative Advantage Index}

Merupakan salah satu indicator yang dapat menunjukkan perubahan keunggulan komperatif suatu Negara. Index ini menunjukkan perbandingan antara pangsa ekspor suatu komoditas atau sekelompok komoditas suatu Negara terhadap pangsa ekspor komoditas tersebut dari seluruh dunia. Dengan perkataan lain, Indek RCA menunjukkan keunggulan komperatif atau daya saing ekspor dari suatu Negara dalam suatu komoditas terhadap dunia. Jika nilai indeks RCA dari suatu Negara untuk suatu komoditi tertentu lebih besar dari satu (1) berarti Negara bersangkutan mempunyai keunggulan komperatif (diatas rata-rata dunia) untuk komoditi tersebut, sebaliknya bila lebih kecil dari satu (1) maka keunggulan komperatif untuk komoditas tersebut rendah. Secara matematis, Indeks RCA adalah :

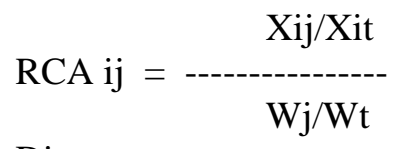

Dimana,

$\mathrm{Xij}=$ Nilai ekspor komoditas $\mathrm{j}$ dari Negara $\mathrm{i}$

$\mathrm{Xit}=$ Nilai ekspor total (produk $\mathrm{j}$ dan lainnya)

$\mathrm{Wj}=$ Nilai ekspor komoditas $\mathrm{j}$ di dunia

$\mathrm{Wt}=$ Nilai ekspor total dunia

\section{Real Effective Exchange Rate}

Nilai tukar efektif riil (REER), sering digunakan sebagai salah satu indeks untuk mengukur tingkat daya saing ekspor suatu Negara. Nilai Tukar riil adalah nilai tukar nominal dibagi rasio indeks harga di dalam negeri dan di luar negeri (Negara mitra dagang). Nilai tukar riil dapat didefinisikan sebagai daya beli relatif dari output domestik, yakni harga dari barang luar negeri ( impor) yang diukur dalam bentuk barang domestik (ekspor). Secara sederhana dapat dirumuskan sebagai berikut :

$$
\text { V = --------- }
$$

Dimana,

$\mathrm{V}=$ Nilai tukar riil

$\mathrm{V} \quad=$ Nilai tukar nominal 

Pln = Indeks harga diluar negeri (barang impor) dalam mata uang asing (misalnya dolar AS)
Pdn = Indeks harga di dalam negeri (barang ekspor) dalam mata uang domestik (rupiah)

\section{Analisis SWOT}

Menurut Rangkuti (2000), Analisis SWOT adalah identifikasi berbagai faktor secara sistematis untuk merumuskan strategi perusahaan. Analisis ini didasarkan pada logika yang dapat memaksimalkan kekuatan (Strength) dan peluang (opportunities), namun secara bersamaan dapat meminimalkan kelemahan (Weaknesses) dan ancaman (Threats).

o Peluang adalah situasi penting yang menguntungkan dalam lingkungan perusahaan.

o Ancaman adalah situasi penting yang tidak menguntungkan dalam lingkungan perusahaan.

o Kekuatan adalah sumberdaya, keterampilan atau keunggulan lain terhadap pesaing.

o Kelemahan adalah keterbatasan atau kekurangan dalam sumberdaya, keterampilan dan kapabilitas menghambat kinerja efektif perusahaan.

\section{Matrix SWOT}

Matrix SWOT dapat menggambarkan secara jelas bagaimana peluang dan ancaman eksternal yang dihadapi perusahaan dapat disesuaikan dengan kekuatan dan kelemahan yang dimilikinya.

\begin{tabular}{|c|c|c|}
\hline EFAS & $\begin{array}{l}\text { STRENGTHS (S) } \\
\text { * Tentukan 5-10 faktor } \\
\text { kelemahan internal } \\
\end{array}$ & $\begin{array}{l}\text { WEAKNESSES (W) } \\
\text { * Tentukan 5-10 faktor- factor } \\
\text { kekuatan internal }\end{array}$ \\
\hline OPPORTUNITIES (O) & STRATEGI SO & STRATEGI WO \\
\hline $\begin{array}{l}\text { *Tentukan 5-10 faktor-faktor } \\
\text { peluang eksternal }\end{array}$ & $\begin{array}{l}\text { Ciptakan strategi yang } \\
\text { menggunakan kekuatan untuk } \\
\text { memanfaatkan peluang }\end{array}$ & $\begin{array}{l}\text { Ciptakan strategi yang } \\
\text { meminimalkan kelemahan } \\
\text { untuk memanfaatkan peluang }\end{array}$ \\
\hline TREATHS (T) & STRATEGI ST & STRATEGI WT \\
\hline $\begin{array}{l}\text { *Tentukan 5-10 faktor-faktor } \\
\text { ancaman eksternal }\end{array}$ & $\begin{array}{l}\text { Ciptakan strategi yang } \\
\text { menggunakan kekuatan untuk } \\
\text { mengatasi ancaman }\end{array}$ & $\begin{array}{l}\text { Ciptakan strategi yang } \\
\text { meminimalkan kelemahan dan } \\
\text { menghindari ancaman }\end{array}$ \\
\hline
\end{tabular}

Tahapan Analisis SWOT

- Menyusun Matrik EFAS dan IFAS

- Penentuan Matrix Grand Strategi

- Formulasi strategi dengan matrix SWOT

- Rekomendasi Strategi yang dijalankan 


\section{Metode Penelitian}

Jenis penelitian ini adalah analisis data skunder. Data diperoleh dari internet dan sumber data lain yang relevan. Analisis ini dilakukan dengan mengkaji tingkat keunggulan komperatif ekspor udang beku Indonesia dibandingkan dengan negara lain. Ada dua pendekatan yang digunakan dalam pengukuran keunggulan komperatif dalam kasus ekspor udang beku Indonesia sebagai berikut.

o Pertama, Domestic Resource Cost (DRC), pendekatan ini digunakan untuk memperkirakan tingkat keunggulan komperatif dari produk ditinjau dari sisi biaya

o Kedua, Revealed Comparative Advantage (RCA), pendekatan ini digunakan untuk mengetahui kinerja ekspor suatu Negara

Setelah diketahui posisi kinerja ekspor Indonesia dibanding negara lain, selanjutnya merumuskan kebijaksanaan/strategi yang perlu ditempuh Indonesia dengan menggunakan bantuan analisis SWOT

\section{PEMBAHASAN}

\section{Indikator Perekonomian Indonesia terhadap Perekonomian Dunia}

Untuk mendapatkan penilaian yang obyektif tentang kondisi perekonomian Indonesia selain dengan membandingkan trend indikator ekonomi dari waktu ke waktu juga dapat dibandingkan dengan kondisi perekonomian negara lainnya. 
Tabel 1 Indikator Perekonomian Dunia Tahun 1994 -2005

\begin{tabular}{|c|c|c|c|c|c|c|c|c|}
\hline \multirow[t]{2}{*}{ Wilayah } & \multicolumn{3}{|c|}{$\begin{array}{c}\text { Pertumbuhan PDB Riil } \\
\text { (\%) }\end{array}$} & \multicolumn{3}{|c|}{ Inflasi (\%) } & \multirow{2}{*}{$\begin{array}{l}\text { Transaksi } \\
\text { Ber-jalan } \\
\text { (Milyar } \\
\text { US\$) } \\
1994\end{array}$} & \multirow{2}{*}{$\begin{array}{l}\text { PDB riil per } \\
\text { kapita (US\$) } \\
1994\end{array}$} \\
\hline & 1994 & 1995* & $\begin{array}{l}1996- \\
2005^{* *}\end{array}$ & 1994 & $1995^{* *}$ & $\begin{array}{l}1996- \\
2005^{* *}\end{array}$ & & \\
\hline Dunia & 2,90 & 2,80 & 3,50 & 3,00 & 3,20 & 3,50 & $(82,00)$ & $4.560,00$ \\
\hline G-7 & 2,90 & 2,30 & 2,80 & 1,60 & 2,10 & 2,70 & $(40,50)$ & $25.650,00$ \\
\hline $\begin{array}{l}\text { Amerika } \\
\text { Serikat }\end{array}$ & 4,10 & 3,20 & - & 2,10 & 2,00 & - & $(151,00)$ & $25.800,00$ \\
\hline Jepang & 0,50 & 0,40 & - & 0,10 & 0,60 & - & 129,00 & $36.730,00$ \\
\hline Jerman & 2,90 & 2,10 & - & 2,30 & 2,90 & - & $(21,70)$ & $22.445,00$ \\
\hline $\begin{array}{l}\text { Asia } \\
\text { Timur \& } \\
\text { Pasifik }\end{array}$ & 9,70 & 9,20 & 7,90 & 6,10 & 8,60 & 5,80 & $(18,80)$ & 880,00 \\
\hline Cina & 12,20 & 10,20 & - & 16,30 & 12,70 & - & 7,20 & 440,00 \\
\hline $\begin{array}{l}\text { Korea } \\
\text { Selatan } \\
\end{array}$ & 8,00 & 9,30 & - & 5,50 & 4,70 & - & $(5,30)$ & $8.560,00$ \\
\hline Indonesia & 7,30 & 7,50 & - & 6,90 & 8,90 & - & $(3,80)$ & 920,00 \\
\hline $\begin{array}{l}\text { Asia } \\
\text { Selatan } \\
\end{array}$ & 5,70 & 5,50 & 5,40 & 10,40 & 9,00 & 6,40 & $(3,20)$ & 320,00 \\
\hline India & 6,10 & 5,80 & - & 10,50 & 9,00 & - & 1,30 & 320,00 \\
\hline $\begin{array}{l}\text { Amerika } \\
\text { Latin \& } \\
\text { Karibia } \\
\end{array}$ & 4,90 & 0,90 & 3,80 & 15,90 & 11,10 & 8,70 & $(46,60)$ & $3.460,00$ \\
\hline Brazil & 5,80 & 4,20 & - & $2.284,00$ & 90,10 & - & $(1,90)$ & $3.490,00$ \\
\hline Meksiko & 3.60 & (6.90) & - & 7,30 & 55,70 & - & $(28,90)$ & $4.240,00$ \\
\hline Argentina & 7,40 & $(3,20)$ & - & 1,80 & 1,30 & - & $(10,00)$ & $8.290,00$ \\
\hline $\begin{array}{l}\text { Timur } \\
\text { Tengah } \\
\text { dan Afrika } \\
\text { Utara }\end{array}$ & 2,10 & 2,50 & 2,90 & 4,60 & 5,90 & 6,30 & $(15,60)$ & $1.600,00$ \\
\hline Iran & 2,40 & 2,70 & - & 35,40 & 46,10 & - & 2,60 & $1.010,00$ \\
\hline Mesir & 2,00 & 2,50 & - & 8,20 & 7,30 & - & 0,20 & 750,00 \\
\hline Algeria & $(1,00)$ & 3,50 & - & 27,90 & 24,10 & - & $(1,80)$ & $1.550,00$ \\
\hline $\begin{array}{l}\text { Afrika } \\
\text { Sub } \\
\text { Sahara } \\
\end{array}$ & & & & & & & & \\
\hline $\begin{array}{l}\text { Afrika } \\
\text { Selatan }\end{array}$ & 2,40 & 3,40 & - & 10,30 & 10,20 & - & $(0,40)$ & $2.970,00$ \\
\hline Nigeria & 2,50 & 0,50 & - & 37,00 & 47,10 & - & 1,60 & 330,00 \\
\hline
\end{tabular}

**) Forecast

*) Estimate

Sumber data : Global Economic Prospect and Developing Countries, World Bank 1996 
Pada Tabel 1, terlihat gambaran Product Domestic Bruto riil Indonesia pada tahun 1995 mencapai 7,50\%. Jika dibandingkan dengan rata-rata PDB riil dunia yang mencapai 2,80\%, jauh diatas rata- rata dunia. Hal ini menunjukkan bahawa aktivitas perekonomian Indonesia berjalan dengan baik yang ditandai oleh tingginya produksi barang/jasa Indonesia.

Kondisi transaksi berjalan yang menggambarkan aliran dana masuk dan keluar Indonesia masih lebih kecil jika dibandingkan dengan rata-rata dunia walaupun transaksi berjalan Indonesia masih mengalami defisit sebesar US\$ 3,80 Millyar. Termasuk dalam transaksi berjalan ini adalah aliran dana masuk dan keluar yang berasal dari ekspor dan impor. Pada tahun 1995 tingkat kesejahteraan masyarakat Indonesia masih diatas rata-rata masyarakat dunia. Hal ini menunjukkan terjadinya peningkatan yang cukup signifikan dibanding kondisi pada awal kemerdekaan Indonesia. Sebagai konsekuensi dari tingginya aktivitas perekonomian, kondisi inflasi Indonesia sebesar 8,90\% diatas rata-rata dunia sebesar 3,20\%. Namun tingkat inflasi sebesar ini relatif masih dapat dikendalikan dan tidak dalam kondisi yang dapat membahayakan perekonomian Indonesia. 
Tabel 2 menggambarkan indikator perekonomian kawasan ASEAN dan APEC dimana Indonesia berada di dalamnya. Produk Domestik Bruto Indonesia masih diatas rata-rata PDB ASEAN, namun pendapatan perkapita penduduk Indonesia masih dibawah rata-rata pendapatan per kapita penduduk ASEAN tetapi diatas kawasan APEC. Hal ini menunjukkan bahwa tingkat kesejahteraan masyarakat Indonesia masih dibawah rata-rata masyarakat kawasan ASEAN, tetapi diatas tingkat kesejahteraan masyarakat kawasan APEC. Kalau disimak lebih detail, neraca perdagangan Indonesia tahun 1995, terlihat bahwa neraca perdagangan Indonesia mengalami surplus US\$ 4,5 milliar jika dibanding dengan kawasan ASEAN yang mengalami defisit US\$ 5,47 millliar dan kawasan APEC defisit US\$ 4,99. Menurut ITC (2001), kinerja ekspor beberapa produk Indonesia adalah sebagai berikut.

Tabel 3 Rangking Kinerja Ekspor Kelompok Produk Indonesia

\begin{tabular}{lcc}
\hline & RCA & RANK \\
\hline Minerals & 85 & 1 \\
Wood Products & 57 & 2 \\
Clothing & 40 & 3 \\
Textiles & 16 & 4 \\
Leather products & 14 & 5 \\
Fresh Food & 4 & 8 \\
Cons. Electronics & 6 & 7 \\
Processed food & 4 & 8 \\
Misc. Manufacturing & -2 & 9 \\
Electronic components & -10 & 10 \\
Basic manufacturing & -25 & 11 \\
Transport equipment & -30 & 12 \\
Chemicals & -48 & 13 \\
Non-electric machinery & -115 & 14 \\
\hline
\end{tabular}

Data tersebut menunjukkan bahwa pada periode tersebut ekspor Indonesia yang mempunyai prospek yang baik adalah bahan pertambangan, kayu olahan, pakaian, tekstil produk kulit, makanan segar dan lain-lain. Terlihat bahwa udang beku yang termasuk dalam kelompok makanan segar menempati urutan ke 6 dari komoditas/kelompok komoditas yang di ekspor Indonsia atau dapat pula dikatakan selama kurun waktu tersebut udang beku menduduki kinerja eskpor ke 6, hal ini menunjukkan bahwa investasi dan usaha dibidang kelautan masih sangat rendah.

\section{A. Status Ekspor Udang Beku Indonesia}

Pasar Utama ekspor udang beku adalah USA, Jepang, Uni Eropa, China dan Singapura. Thailand mengekspor sekitar 1,000 milliar US\$ (80\% dari produk keseluruhan tahun 1999). Pesaing utama Thailand dalam ekspor udang beku di pasar Amerika adalah Ekuador, Mexico, India dan Indonesia. Sementara itu pesaing utama di Jepang adalah : Indonesia, India, Vietnam dan China. Peringkat kinerja ekspor udang beku suatu negara 
akan berbeda untuk pasar dan waktu yang berbeda. Keunggulan bersaing suatu produk tidak terlepas dari keunggulan komperatif dari proses produksi komoditas tersebut, seperti yang terlihat pada tabel dibawah ini:

Tabel 4 Peringkat Efisiensi Produksi (DRC) Negara Pengekspor Udang Beku

\begin{tabular}{lcccc}
\hline \multicolumn{1}{c}{ Negara } & Xsn & Ys & Xst & DRC \\
\hline China & 2.1 & 4.8 & 1.7 & 0.7 \\
India & 2.2 & 6.5 & 1.7 & 0.5 \\
Indonesia & 1.9 & 6.4 & 1.6 & 0.4 \\
Malaysia & 1.7 & 7.5 & 2.0 & 0.3 \\
Philipina & 3.0 & 7.0 & 2.3 & 0.6 \\
Taiwan & 4.0 & 12.3 & 1.5 & 0.4 \\
Thailand & 1.6 & 6.8 & 1.7 & 0.3 \\
Sri Lanka & 1.5 & 8.5 & 2.2 & 0.2 \\
\hline
\end{tabular}

Sumber : Songsak et al, 2000

Tabel 4 menunjukkan bahwa dari delapan negara penghasil udang beku yang memiliki keunggulan komperatif ditingkat produksi udang beku apabila dilakukan pemeringkatan adalah sebagai berikut: Srilangka, Thailand, Malaysia, Indonesia, Taiwan India, Philipina dan China. Dari segi efisiensi dalam kegiatan produksi udang beku terlihat bahwa Indonesia berada di peringkat ke 5. Apabila dijabarkan lebih lanjut bahwa biaya produksi per unit udang beku masih dibawah Malaysia dan Thailand untuk kawasan ASEAN, hal ini akan berpengaruh terhadap harga jual produk Indonesia yang kurang kompetitif jika dibanding dengan negara lain. Selanjutnya Songsak et al, menjelaskan kondisi kinerja ekspor (RCA) udang beku beberapa negara pengekspor udang beku untuk pasar Amerika dan Jepang sebagai berikut.

Tabel 5 Kinerja Ekspor (RCA) Negara Pengekspor Udang Beku di Pasar Amerika (1990-1999)

\begin{tabular}{ccccccc}
\hline Tahun & Ecuador & India & Indonesia & Mexico & Taiwan & Thailand \\
\hline 1990 & 0.9320 & 1.0065 & 0.9501 & 0.9164 & 0.7722 & 0.8943 \\
1991 & 1.1447 & 1.1861 & 1.1978 & 1.2017 & 0.7136 & 1.1441 \\
1992 & 1.0613 & 1.0552 & 1.0906 & 1.0976 & 0.6902 & 1.0555 \\
1993 & 1.0453 & 1.0044 & 1.0390 & 1.0926 & 0.6399 & 1.0708 \\
1994 & 1.0822 & 0.9802 & 1.0735 & 1.1016 & 0.6854 & 1.0833 \\
1995 & 1.0930 & 1.0501 & 1.0420 & 1.0852 & 0.6942 & 1.0715 \\
1996 & 1.0932 & 1.0537 & 1.0516 & 1.0837 & 0.5275 & 1.0804 \\
1997 & 1.0955 & 1.0607 & 1.0588 & 1.0775 & 0.6510 & 1.0820 \\
1998 & 1.0955 & 1.0193 & 1.0735 & 1.0892 & 0.4921 & 1.0850 \\
1999 & 1.0409 & 0.9557 & 1.0065 & 0.9426 & 0.2817 & 1.0580 \\
\hline
\end{tabular}

Sumber: Songsak et al, 2000

Dari Tabel 5 dapat dijelaskan bahwa negara pemasuk udang beku ke Amerika Serikat adalah Ekuador, India, Indonesia, Mexico, Taiwan dan Thailand. Dari data diatas terlihat pula bahwa posisi kinerja ekspor udang beku Indonesia dan Thailand ke Amerika 
Serikat sepintas terlihat hampir sama, yaitu masih diatas rata-rata dunia tetapi apabila disimak data dua tahun terakhir terjadi penurunan kinerja ekspor Indonesia. Apabila dibandingkan dengan Thailand penurunan kinerja ekspor udang bekunya ke Amerika tidak sedrastis Indonesia.

Tabel 6 Kinerja Ekspor (RCA) Negara Pengekspor Udang Beku di Pasar Jepang (1994-1998)

\begin{tabular}{ccccccc}
\hline Tahun & China & Indonesia & India & Phillippines & Thailand & Vietnam \\
\hline Cooked & & & & & & \\
1994 & 0.6317 & 1.2619 & 0.0775 & 0.0000 & 2.9247 & 0.0000 \\
1995 & 0.4224 & 1.1741 & 0.0000 & 0.0000 & 3.1484 & 0.0000 \\
1996 & 0.2010 & 1.0668 & 0.0000 & 0.0000 & 4,5219 & 0.0000 \\
1997 & 0.6267 & 1.1688 & 0.0000 & 0.0000 & 4.9355 & 0.1414 \\
1998 & 1.2246 & 0.8526 & 0.0000 & 0.0000 & 5.6280 & 0.2335 \\
\hline
\end{tabular}

Dari Tabel 6 terlihat bahwa negara pemasuk udang beku yang sudah di olah ke pasar Jepang adalah China, Indonesia, India, Thailand dan Vietnam. Diantara negara tersebut, negara yang menunjukkan kinerja ekspor yang paling tinggi adalah Thailand dan Indonesia berada pada posisi kedua. Kedua pasar tersebut (Amerika dan Jepang) merupakan pasar tujuan ekspor udang beku dari negara-negara pengekspor udang beku sehingga dapat diasumsikan sebagai pasar ekspor udang beku dunia.

Dengan memperhatikan RCA Indonesia di pasar Amerika dan Jepang serta memperhatikan DRC dari beberapa negara pengekspor, dapat dikatakan bahwa status kinerja ekspor udang beku Indonesia masih dibawah Thailand, terlebih lebih dengan tingginya biaya produksi udang beku Indonesia di bandingkan dengan Thailand menyebabkan Thailand lebih unggul dalam memasarkan produk udang bekunya ke pasaran dunia. Melihat kondisi ini, sudah seyogyanya pemerintah Indonesia melakukan evaluasi dan pembenahan dan revitalisasi terhadap potensi ekonomi hasil kelautan Indonesia khususnya terhadap kinerja ekspor udang beku Indonesia. Untuk itu perlu melakukan Analisis SWOT untuk mendapatkan rekomendasi tentang strategi/ kebijaksanaan yang perlu diambil pemerintah Indonesia untuk meningkatkan kinerja ekspornya, karena potensi Indonesia dari sisi Sumber Daya Alam memungkinkan untuk ini.

\section{B. Analisis SWOT}

Analisis SWOT adalah identifikasi berbagai faktor secara sistematis untuk merumuskan strategi. Analisis ini didasarkan pada logika yang dapat memaksimalkan kekuatan (Strengths) dan peluang (Opportunities), namun secara bersamaan dapat meminimalkan kelemahan (Weakness), dan ancaman (Threats). 


\section{Matrik IFAS dan EFAS}

\section{Tabel 7 Matrik IFAS}

\begin{tabular}{|c|c|c|c|}
\hline Faktor Strategi Internal & Bobot & Rating & Skor \\
\hline \multicolumn{4}{|l|}{ Kekuatan } \\
\hline $\begin{array}{l}\text { Potensi ekonomi kelautan dan keragaman } \\
\text { sumberdaya hayati }\end{array}$ & 0,15 & 4 & 0,6 \\
\hline Surplus stok sumberdaya perikanan & 0,1 & 3 & 0,3 \\
\hline $\begin{array}{l}\text { Sumber daya manusia tersedia cukup banyak } \\
\text { dengan upah yang relative rendah }\end{array}$ & 0,08 & 3 & 0,24 \\
\hline Lahan Budidaya udang yang sangat luas & 0,08 & 3 & 0,24 \\
\hline Mendapatkan prioritas ekspor dari pemerintah & 0,06 & 2 & 0,12 \\
\hline $\begin{array}{l}\text { Kelembagaan budidaya dan pasca panen yang } \\
\text { mendukung ekspor }\end{array}$ & 0,04 & 1 & 0,04 \\
\hline \multicolumn{4}{|l|}{ Kelemahan } \\
\hline $\begin{array}{l}\text { Kebijaksanaan pembangunan ekonomi yang } \\
\text { belum memihak ke bidang kelautan }\end{array}$ & 0,12 & 1 & 0,12 \\
\hline $\begin{array}{l}\text { Investasi dan usaha di bidang kelautan masih } \\
\text { rendah }\end{array}$ & 0,1 & 2 & 0,2 \\
\hline $\begin{array}{l}\text { Rendahnya pemahaman stakeholders di bidang } \\
\text { kelautan }\end{array}$ & 0,08 & 2 & 0,16 \\
\hline $\begin{array}{l}\text { Jaminan keamanan dan kepastian hukum yang } \\
\text { kurang kondusif untuk berlangsung-nya kegiatan } \\
\text { budidaya }\end{array}$ & 0,08 & 2 & 0,16 \\
\hline Infrastruktur pembangunan sector perikanan & 0,06 & 3 & 0,18 \\
\hline Skill tenaga budidaya udang masih rendah & 0,05 & 4 & 0,2 \\
\hline Total & 1,00 & & 2,56 \\
\hline
\end{tabular}

Sumber: Penulis 
Tabel 8 Matriks EFAS

\begin{tabular}{|c|c|c|c|}
\hline Faktor Strategi Internal & Bobot & Rating & Skor \\
\hline \multicolumn{4}{|l|}{ Peluang } \\
\hline $\begin{array}{l}\text { Permintaan terhadap barang dan jasa kelautan terus } \\
\text { meningkat }\end{array}$ & 0,2 & 4 & 0,8 \\
\hline Harga udang beku di pasar dunia cukup baik & 0,15 & 3 & 0,45 \\
\hline $\begin{array}{l}\text { Kerjasama ekonomi regional akan menciptakan pasar } \\
\text { baru dan penurunan bea masuk }\end{array}$ & 0,1 & 2 & 0,2 \\
\hline $\begin{array}{l}\text { Kesadaran masyarakat dunia untuk mengurangi } \\
\text { konsumsi sumber protein yang berasal dari hewan } \\
\text { besar }\end{array}$ & 0,1 & 1 & 0,1 \\
\hline \multicolumn{4}{|l|}{ Ancaman } \\
\hline Standar mutu yang diterapkan Negara tujuan ekspor & 0,15 & 1 & 0,15 \\
\hline $\begin{array}{l}\text { Potensi efisiensi biaya (DRC) dari beberapa negara } \\
\text { pesaing yang semakin rendah }\end{array}$ & 0,1 & 2 & 0,2 \\
\hline Infrastruktur negara pesaing yang lebih memadai & 0,1 & 3 & 0,3 \\
\hline $\begin{array}{l}\text { Penelitian dan pengembangan serta kelembagaan } \\
\text { negara pesaing yang lebih memadai }\end{array}$ & 0,05 & 3 & 0,15 \\
\hline Pencurian hasil laut yang dilakukan oleh kapal asing & 0,05 & 4 & 0,2 \\
\hline Total & 1 & & 2,55 \\
\hline
\end{tabular}

Sumber : Penulis

2. Hasil Analisis SWOT

Berdasarkan analisis terhadap kondisi internal dan eksternal potensi kelautan khususnya udang beku Indonesia, letak strategi pengembangan ekspor udang beku Indonesia adalah sebagai berikut.

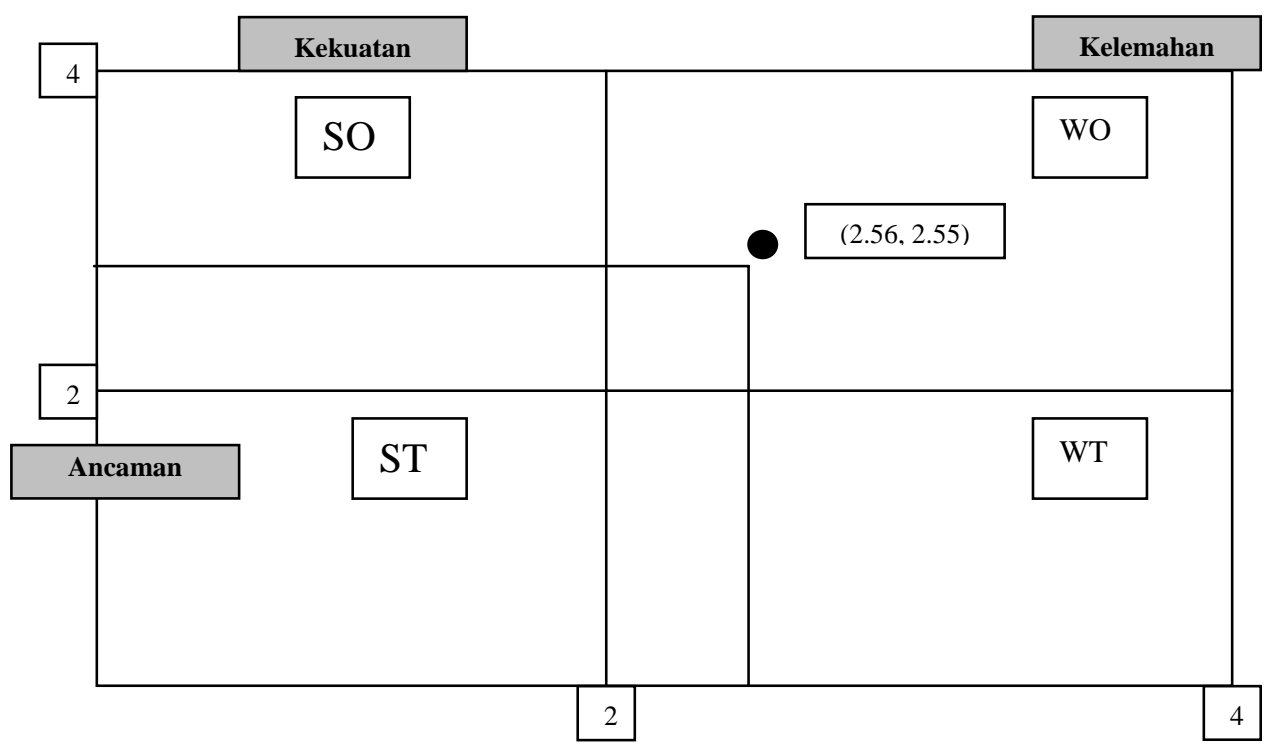

Gambar 1 Posisi Strategi Ekspor Hasil Perikanan Indonesia 
Posisi ekspor hasil perikanan Indonesia adalah pada posisi WO, yaitu menciptakan strategi dengan meminimalkan kelemahan untuk memanfaatkan peluang yang ada. Berkaitan dengan strategi tersebut untuk lebih jelasnya dapat dilihat pada Tabel 9 sebagai berikut.

\section{Matrik SWOT}

Tabel 9 Matriks SWOT

\begin{tabular}{|c|c|c|}
\hline IFAS & $\begin{array}{l}\text { STRENGTHS (S) } \\
\text { - } \quad \text { Potensi ekonomi kelautan } \\
\text { dan keragaman sumber- } \\
\text { daya hayati } \\
\text { - } \quad \text { Surplus stok sumberdaya } \\
\text { perikanan } \\
\text { - Sumber daya manusia } \\
\text { tersedia cukup banyak } \\
\text { dengan upah yang relative } \\
\text { rendah } \\
\text { - Lahan Budidaya udang yang } \\
\text { - } \quad \text { Mengat luas } \\
\text { - } \text { ekspor dari pemerintah } \\
\text { pelembagaan budidaya dan } \\
\text { mendukung ekspor }\end{array}$ & 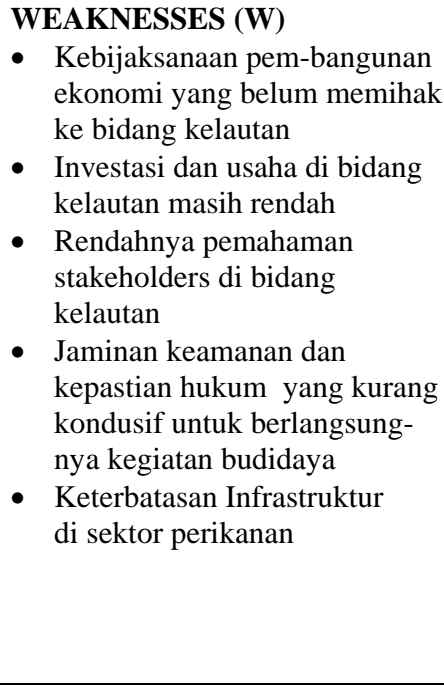 \\
\hline $\begin{array}{l}\text { OPPORTUNITIES (O) } \\
\text { - } \quad \text { Permintaan terhadap } \\
\text { barang dan jasa kelautan } \\
\text { terus meningkat } \\
\text { - } \\
\text { Harga udang beku di pasar } \\
\text { dunia cukup baik } \\
\text { - } \\
\text { Kerjasama ekonomi } \\
\text { regional akan menciptak- } \\
\text { an pasar baru dan } \\
\text { penurunan bea masuk } \\
\text { - Kesadaran masyarakat } \\
\text { dunia untuk mengurangi } \\
\text { konsumsi sumber protein } \\
\text { yang berasal dari hewan } \\
\text { besar }\end{array}$ & $\begin{array}{l}\text { - Mengoptimalkan } \\
\text { pendayagunaan potensi } \\
\text { kelautan Indonesia untuk } \\
\text { merespons permintaan pasar } \\
\text { yang terus meningkat } \\
\text { - Memanfaatkan kelebihan } \\
\text { sumberdaya Indonesia } \\
\text { untuk dapat menciptakan } \\
\text { keunggulan bersaing } \\
\text { - Meningkatkan sarana } \\
\text { pendukung pengolahan hasil } \\
\text { perikanan Indonesia } \\
\text { - Menigkatkan kerjasama di } \\
\text { bidang perikanan dengan } \\
\text { Negara-negara ASEAN dan } \\
\text { APEC dalam rangka } \\
\text { menggali sumber pasar } \\
\text { baru. }\end{array}$ & $\begin{array}{l}\text { - Membuat kebijaksana-an } \\
\text { ekonomi yang lebih } \\
\text { memprioritaskan pem- } \\
\text { bangunan ekonomi di bidang } \\
\text { perikanan dan kelautan } \\
\text { melalui peningkatan investasi, } \\
\text { kredit usaha dan lain-lain. } \\
\text { - } \text { Sosialisasi potensi kelautan } \\
\text { Indonesia dan prospek pasar } \\
\text { untuk menggairahkan stake } \\
\text { horlders melakukan investasi } \\
\text { dan pem-bangunan infra } \\
\text { struktur yang mendukung } \\
\text { kegiatan perikanan } \\
\text { Menciptakan stabilisasi } \\
\text { keamanan yang kondu-sif dan } \\
\text { meningkatkan kepastian } \\
\text { hukum di dunia usaha/bisnis }\end{array}$ \\
\hline
\end{tabular}




\begin{tabular}{|c|c|c|}
\hline $\begin{array}{l}\text { THREATS (T) } \\
\text { - } \\
\text { Standar mutu yang } \\
\text { diterapkan Negara tujuan } \\
\text { ekspor } \\
\text { - } \\
\text { Potensi efisiensi biaya } \\
\text { (DRC) dari beberapa } \\
\text { negara pesaing yang } \\
\text { semakin rendah } \\
\text { - } \text { Infrastruktur negara } \\
\text { pesaing yang lebih } \\
\text { memadai } \\
\text { - Penelitian dan } \\
\text { pengembangan serta } \\
\text { kelembagaan negara } \\
\text { pesaing yang lebih } \\
\text { memadai } \\
\text { Pencurian hasil laut yang } \\
\text { dilakukan oleh kapal asing }\end{array}$ & $\begin{array}{l}\text { - Meningkatkan kualitas } \\
\text { ekspor hasil perikanan } \\
\text { melalui optimalisasi } \\
\text { pendayagunaan kelembagaan } \\
\text { budidaya dan pasca panen } \\
\text { - Memanfaatkan keunggulan } \\
\text { sumberdaya untuk menekan } \\
\text { biaya produksi } \\
\text { - Merevitalisasi kelembagaan } \\
\text { di sector perikanan untuk } \\
\text { menciptakan produk-produk } \\
\text { hasil perikanan yang } \\
\text { berkualitan } \\
\text { - Meningkatkan kemampuan } \\
\text { dan peralatan untuk } \\
\text { mencegah terjadinya } \\
\text { pencurian hasil laut } \\
\text { Indonesia }\end{array}$ & $\begin{array}{l}\text { - Meningkatkan investasi di } \\
\text { bidang perikanan untuk } \\
\text { memperkuat infrastrukutur. } \\
\text { - Mengalokasikan dana penelitian } \\
\text { dan pengembangan yang lebih } \\
\text { memadai dalam rangka } \\
\text { meningkatkan mutu produk } \\
\text { hasil perikanan } \\
\text { - Efisiensi }\end{array}$ \\
\hline
\end{tabular}

Sumber : Penulis

\section{Penerapan Strategi}

Berdasarkan analisis SWOT, posisi strategi adalah WO, dengan penjabaran sebagai berikut.

- Permintaan terhadap produk hasil perikanan khususnya udang beku di pasar dunia masih cukup banyak yang belum dapat dipenuhi, sedangkan potensi sumberdaya kelautan Indonesia masih cukup besar dan belum ditangani secara optimal. Untuk memenuhi permintaan pasar dunia, Indonesia harus menggalakkan usaha disektor ini dengan meningkatkan investasi salah satunya melalui sosialisasi prospek ekspor udang beku kepada para stakeholders baik didalam maupun diluar negeri. Dalam hal ini dituntut peran pemerintah untuk menerapkan kebijaksanaan yang lebih memprioritaskan pembangunan ekonomi di sector perikanan dan kelautan. Sejak era reformasi ini pemisahaan sub sector perikanan dari sektor pertanian telah dilakukan antara lain dengan memisahkan Direktorat Jenderal Perikanan dari Departemen Pertanian menjadi Departemen Perikanan dan Kelautan. Hal ini untuk lebih memfokuskan peranan sektor perikanan dalam pembangunan ekonomi nasional. Disamping itu pemerintah saat ini tengah bersungguh-sungguh menggali potensi dan mengoptimalkan pendayagunaan/pembangunan di sektor pertanian, perikanan dan kehutanan melalui program revitalisasi ketiga sektor pembangunan tersebut. Pencanangannya telah dilakukan oleh Presiden RI pada pertengahan tahun 2005 yang lalu di Bendungan Jatiluhur, Jawa Barat. Hal ini mengindikasikan bahwa pemerintah telah bersungguh-sungguh akan meningkatkan potensi ketiga sektor ini yang selama ini selalu ditinggalkan. Selain itu kepastian hukum dalam dunia bisnis perlu terus dikembangkan.Seringkali para investor dari luar negeri 
mendapatkan kondisi ketidak konsistenan kebijaksanaan/ peraturan antara pemerintah pusat dan daerah yang pada akhirnya banyak merugikan pihak investor. Cukup banyak kasus-kasus yang berkaitan dengan ketidakpastian hukum ini yang pada akhirnya menyebabkan para investor terutama yang berasal dari luar negeri mengadukan persengketaan ini ke Badan Arbitrase Internasional yang pada akhirnya akan merugikan pihak Indonesia. Kedepan pemerintah harus berupaya untuk melaksanakan setiap kebijaksanaan bisnis/berusaha secara konsisten serta menjamin tidak terjadinya kontradiksi antara peraturan-peraturan yang diterbitkan oleh pemerintah pusat dan daerah.

- Berkembangnya investasi disuatu negara tidak terlepas dari kondisi keamanan dan ketertiban masyarakat yang kondusif dinegara tersebut serta kepastian hukumnya. Pertimbangan para investor untuk menanamkan investasinya disuatu Negara pertama-tama didasarkan pada perhitungan kelayakan binis tersebut dari sudut pandang keuntungan yang didapat dimasa yang akan datang. Hal ini baru dapat terwujud bila persyaratan keamanan berlangsungnya kegiatan investasi dapat terjamin. Sebagai contoh, pada akhir 1997/awal 1998, pada saat krisis moneter sedang menimpa Indonesia yang disertai oleh krisis multidimensi, kondisi keamanan dan ketertiban masyarakat berada dalam kondisi terburuk dimana banyak lahan-lahan budidaya perikanan siap panen dijarah oleh masyarakat sekitarnya. Sebagai akibatnya banyak para investor yang mengalihkan investasi keluar Indonesia karena kondisi yang tidak menguntungkan tersebut.

- Menciptakan suasana aman dan tertib dilingkungan masyarakat merupakan persyaratan yang mutlak diperlukan untuk menjamin kelangsungan kegiatan investasi di Indonesia. Seiring dengan terjadinya krisis moneter di Indonesia yang berimbas pada terjadinya krisis multidimensi mengharuskan pemerintah untuk menata kembali tatanan kehidupan bermasyarakat dan bernegara. Pemerintahan yang kuat yang telah mendapat legitimasi dari sebahagian besar rakyatnya merupakan persyaratan mutlak untuk mencapai hal tersebut. Disamping itu disiplin dan loyalitas yang tinggi dari para penegak hukum sangat diperlukan untuk mengatasi hal tersebut. Dimasa yang akan datang pemerintah perlu melakukan evaluasi yang mendalam terhadap aparatur pemerintah khususnya personil penegak hukum melalui sistem reward dan punishment yang jelas dan tegas. Dengan cara ini diharapkan para penegak hukum ini akan bekerja dengan loyalitas yang tinggi, jujur dan mempunyai moralitas yang tinggi. 


\section{PENUTUP}

\section{Simpulan}

Berdasarkan kajian yang dilakukan, diperoleh simpulan sebagai berikut.

1. Kondisi tingkat kesejahteraan masyarakat Indonesia yang dicerminkan oleh tingkat pendapatan perkapita masih di bawah negara-negara ASEAN.

2. Kinerja ekspor produk hasil perikanan Indonesia masih lebih rendah dari negara tetangga kita. Rendahnya kinerja ekspor hasil perikanan Indonesia (ekspor udang beku) disinyalir menjadi salah satu penyebab rendahnya tingkat kesejahteraan masyarakat nelayan di Indonesia.

3. Setelah dilakukan analisis SWOT terhadap posisi strategi ekspor hasil perikanan dan kelautan Indonesia adalah WO, yaitu meminimalkan kelemahan untuk memanfaatkan peluang. Adapun langkah yang perlu dilakukan sebagai berikut.

a. Lebih memprioritaskan pembangunan ekonomi di sektor perikanan dan kelautan.

b. Revitalisasi pembangunan di sektor perikanan dan kelautan dengan mengoptimalkan sumberdaya yang ada.

c. Menjamin keamanan dan kepastian hukum berusaha di sektor perikanan dan kelautan.

\section{Saran}

Untuk dapat merealisasikan potensi ekonomi yang sangat besar menjadi sumber kemajuan dan kemakmuran bangsa, beberapa langkah yang disarankan sebagai berikut.

1. Untuk merangsang investor di sektor perikanan dan kelautan, perlu dilakukan/diterapkan kebijaksanaan perpajakan yang atraktif yang dapat menarik minat para investor.

2. Melakukan kerjasama bilateral dengan beberapa negara yang mempunyai kompetensi dalam pengelolaan sumberdaya lautnya, termasuk kerjasama pemanfaatan teknologi dan infrastruktur dengan sistem bagi hasil tangkapan.

3. Pemerintah membuat kebijaksanaan perbankan yang menyalurkan sebagian kreditnya kepada para nelayan yang membutuhkan kredit usaha. 


\section{DAFTAR PUSTAKA}

Dahuri, R. 2005. Prospek Investasi dan Bisnis di Sektor Perikanan.

Rangkuti, Freddy. 2003. Analisis SWOT: Teknik Membedah Kasus Bisnis. Jakarta. Gramedia Pustaka Utama.

Songsak, et. al. 2000. Thai Shrimp Export. Research Report. Multiple Cropping Centre. Chiang Mai University.

Tambunan, Tulus T.H. 2001. Perekonomian Indonesia. Ghalia Indonesia. 